\title{
ГАЛОГЕНИДЫ 1-АЛЛИЛ- 2-АМИНО-3- \\ КАРБОКСИ(КАРБАЛКОКСИ)-МЕТИЛБЕНЗИМИДАЗОЛИЯ В СИНТЕЗЕ ПОТЕНЦИАЛЬНО БИОЛОГИЧЕСКИ АКТИВНЫХ ПРОИЗВОДНЫХ ИМИДАЗО[1,2-А] БЕНЗИМИДАЗОЛОНОВ-2
}

\author{
О.Н. Жуковская, А.С. Морковник \\ Научно-исследовательский институт физической и органической химии \\ ФГАОУ ВО «Южного Федерального Университета» \\ 344090, Россия, Ростов-на-Дону, пр. Стачки, 194/2.
}

DOI: 10.19163/MedChemRussia2021-2021-414

E-mail:zhukowskaia.ol@yandex.ru

Соли бензимидазолия интереснысвоей разнообразной биологической активностью[1], а также способностью, при наличии необходимых структурных предпосылок, циклизоватьсяв трициклические бензимидазолы. Такие циклизации широко используются, в частности, для получения различных фармакологически активных производных имидазо[1,2-а]бензими-дазола, ряд из которых либо рекомендован к клиническим испытаниям либо, как 9-диэтиламино-2,3дигидроимидазо[1,2-а]бензимидазол (Диабенол) [2], уже прошел их.

В настоящей работе нами исследован синтетический потенциал четвертичных солей 1-аллил-2-амино-3-карбокси(карбалкокси)метилбензимидазолия и их 2-иминобензимидазо-линовых формкак исходных соединений для получения новых функционализированных производных имидазо[1,2-а]бензимидазолонов-2 (например, 1-4). Это позволяет существенным образом расширить диверсификацию библиотеки имидазо[1,2-а]бензимидазолов, доступных для проведения фармакологического тестирования.<smiles>C=CCN1C2=NC(=O)CN2c2ccccc21</smiles>

1

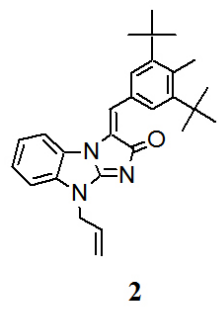

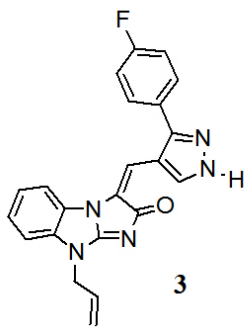<smiles>C=CCN1C2=NC(=O)/C(=C\c3cn(C(C)=O)nc3-c3ccsc3)N2c2ccccc21</smiles>

Работа выполнена прифинансовой поддержке Министерства науки высшего образования РФ, грант FENW-2020-0031 (0852-2020-0031).

\section{Литература}

1. M.Yigit, B.Yigit, P. Taslimi, I. Ozdemir, MKaraman, I.Gulçin. J. Mol. Struct. 2020, 1207, 127802. DOI: 10.1016/j.molstruct.2020.127802.

2. Патент РФ № 2386634 С2. Бюл. Изобретений. 2010.11. 